\title{
Padre Antônio Vieira: uma leitura simbólica da história universal
}

\author{
Marcos Antônio Lopes \\ Universidade Estadual de Londrina
}

E, como tinha a vida e as empresas firmadas por uma escritura de Deus ou por três escrituras, e ao mesmo Deus por fiador de sua palavra e promessas, fé era e não audácia, confiança e não temeridade, empenharse Alexandre nos perigos para conseguir as empresas e dar exemplo de desprezo da vida a seus soldados para os animar às vitórias. Tanta parte teve a profecia nas ações deste grande capitão e no Império deste grande monarca, o qual, se deve a Filipe o ser Alexandre, deve a Daniel o ser Magno.

Antônio Vieira. História do Futuro

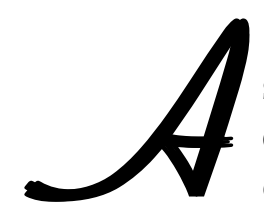

s revelações do padre Vieira fazem dele uma espécie de "pilar cósmico", 1 simplesmente porque o intérprete está de posse do dom de filtrar, em meio aos mistérios, o real sentido de mensagens que não podem ser captadas pelo entendimento de pessoas comuns. $\mathrm{E}$ o autor possui uma ampla idéia dessa sua nova e incomum competência exegética, que é o que basta para dotá-lo de uma sensibilidade apurada no ofício das adivinhações dos sucessos que estão por vir e ainda daqueles outros que, estando já em curso - mas que por serem demasiadamente complexos e por

${ }^{1}$ A expressão é de ELIADE, 1970. 
terem se revelado apenas parcialmente -, carecem de um intérprete que consiga distinguir o real sentido dos emaranhados enredos da história.

Para José van den Besselaar, Vieira não se preocupava em alcançar o sentido histórico do texto bíblico. Ele não se importava em averiguar o que "quis dizer" o texto sagrado. Apenas se aplicava em extrair-lhe uma lição para servir às necessidades de sua atualidade, o que Besselaar denomina por "sentido acomodatício" das Escrituras. ${ }^{2}$ É por esse expediente que, para o pregador, a história de Portugal reprisava a história antiga de Israel, ou melhor, estava prefigurada nas Escrituras. Daí a similaridade entre eventos dos textos bíblicos e acontecimentos de seu tempo, como a invasão do Brasil por povos "heréticos", como os holandeses. É o que se lê, por exemplo, no "Sermão de Santo Antônio", proferido na Bahia, em 1638:

O Texto do nosso thema tresladado ao Cap. $19^{\circ}$. Do $4^{\circ}$. Livro dos Reis, foi tirado do Cap. $37^{\circ}$. de Isaias, o qual como historiador escreveu o successo do sitio de Jérusalem, e como Propheta pintou nelle o da Bahia. E para que não faltasse tambem ao officio de commentador e interprete, no Cap. $26^{\circ}$., cantando a victoria da cidade que tem por nome Salvador, diz que para sua segurança e fortaleza se porá nella o muro e o antemural. ${ }^{3}$

Uma guinada teórica de que Vieira parece ter clara consciência de ser o promotor refere-se à dimensão temporal de sua História. Os exemplos das coisas passadas possuem uma utilidade programática que ele utiliza para os seus curiosíssimos propósitos. Ao ler as profecias de grandes visionários como Isaías e Daniel, ele procura manejá-las de maneira a apontá-las como

${ }^{2}$ Cf. BESSELAAR, 1982.

${ }^{3}$ CF. CALMON, 1933, p. 19. 
os juízos de realização das suas próprias expectativas: Portugal como ponta de lança da Cristandade, naquela fase da história que ele denomina o Quinto Império, em que a "roda da Providência” fez correr em definitivo “... do Oriente ao Ocidente os movimentos políticos".

Conforme ele assegura, a sucessão cronológica e geográfica das monarquias universais "... vai levando seu curso para o Ocidente, havendo de ser, como é de fé, o último império, aonde pode ir parar, senão na gente mais ocidental de todas?". ${ }^{4}$ Dito isso, talvez não seja equivocado afirmar que a dimensão do tempo histórico que predomina na obra visionária desse cortesão polemista seja a do presente vivido, ainda que não se desconsidere que, nessa dimensão de sua obra, o grau de complexidade é bem maior. A rigor, a dimensão do tempo na obra de Vieira não é nem histórica nem natural, mas dramática, porque fundada numa concepção de história sagrada e providencial. 5

Manejando as Sagradas Escrituras como um instrumento de persuasão, que concentra o juízo de autoridades incontestáveis, ele manipula acontecimentos do passado, que são apontados como a garantia infalível do que está por vir. As profecias são escudos defensivos, pois o que está escrito é a própria garantia infalível do sucesso. ${ }^{6}$ Para Vieira, conhecer o futuro é como tentar enxergar nas trevas mais espessas. O futuro é matéria obscura, requer a sensibilidade do profeta. Andar nas trevas e desembaraçar-se dos perigos da escuridão, só se for impelido pelo Espírito Santo. A candeia da profecia é o instrumento de iluminação dessas trevas espessas, o futuro. Para Vieira, os

${ }^{4}$ VIEIRA, Volume XV, 1951, p. 84.

${ }^{5}$ Acerca dessa questão veja-se as formulações de AUERBACH, 2002.

${ }^{6}$ Cf. VIEIRA, 2005, p. 214. 
exemplos da História Sagrada narrados nas Escrituras demonstram claramente ser Portugal a terra da promissão. De fato, ele via Portugal como o país do futuro, o novo centro civilizador da Cristandade.

Ele, Vieira, será o cronista das venturas que hão de vir, e pretende revelar tantas glórias reservadas por Deus à sua pátria a ponto de silenciar todas as Histórias que abordaram as passadas conquistas portuguesas. O novo reino, do qual já se enxergam os prenúncios, não será formado por "retalhos de terra"; os seus limites geográficos terão por "margens os horizontes". Não se tratará de um título vazio o Quinto Império, como o Império Germânico de seu tempo. O Quinto Império será a união de todos os cetros cristãos. Haverá uma única coroa secular e a Providência se encarregará de manter o equilíbrio permanente desse gigante territorial. ${ }^{7}$

Mas Vieira não se ilude quanto aos instrumentos de garantia da paz. Como Maquiavel e como Hobbes, fala em um regime defendido pela justiça da espada, instrumento humano eficaz e necessário. Entretanto, acentua Alcir Pécora, “... é preciso ter claro que a argumentação de Antônio Vieira invariavelmente pressupõe a dimensão ético-religiosa como propriedade eficaz de racionalização das atividades administrativo-burocráticas do Estado". ${ }^{8}$

$\mathrm{Na}$ História do Futuro Vieira ressalta que a singularidade de suas interpretações está em sua capacidade de expor o que nunca ninguém ousou narrar. Nesse sentido, ele é um contrahistoriador que pretende deixar numa posição intelectualmente subalterna nomes como Heródoto, Plutarco, Tácito, Tito Lívio, dentre outros vultos da prestigiosa tradição clássica de historiadores.

\footnotetext{
${ }^{7}$ Cf. VIEIRA, 2005, p. 142.

${ }^{8}$ Cf. NOVAES, 1999, p. 136.
} 
As profecias, ele as cataloga e decodifica, atuando também como difusor das mesmas, o que lhe valeu certas agruras nas barras dos tribunais eclesiásticos. Ao lado dos eventos da história sagrada, ele não dispensava a leitura paralela dos escritores profanos. As leituras de Vieira permitem perceber que ele se comunicava com um conjunto imenso de obras e autores das mais diversas procedências.

Sob esse aspecto, é exuberante o volume de referências autorais feitas por Vieira. Alcir Pécora fala de uma "multidão de autores clássicos" em meio à qual fica difícil "identificar uma linha de frente". ${ }^{9}$ Sócrates, Platão, Aristóteles, Cícero, Plínio, dentre outros, desfilam por suas páginas. ${ }^{10}$

A sabedoria antiga de alguns desses vultos faz autoridade, por se constituir em prefiguração das verdades do cristianismo. Entretanto, ele faz questão de deixar claro que as Sagradas Escrituras são superiores à tradição greco-romana. Dos historiadores cita Xenofonte, Heródoto, Tucídides, Tácito, Flávio Josefo, Tito Lívio. Apesar de recorrer frequentemente aos historiadores, Vieira não se tomava na conta de historiador. As "cousas passadas", quando matéria reveladora do que já foi, não lhe interessavam pelo fato de não serem muito úteis aos seus propósitos de intérprete das coisas em curso e das coisas que viriam. Vieira quis ser levado a sério como decifrador e divulgador de profetas numa Cristandade em vias de uma nova elaboração:

${ }^{9}$ PÉCORA, 1994, p. 73.

${ }^{10}$ Segundo a observação de Luiz Roncari, "No seio da Companhia de Jesus, Vieira pôde adquirir uma vasta cultura européia, tanto dos formuladores da doutrina cristã e católica como dos clássicos gregos e romanos". Cf. RONCARI, 1995, p. 143. 
De maneira que põe Deus a profecia como candeia nas mãos dos profetas, para que, alumiados e guiados da mesma luz os que não somos profetas, possamos entrar com elas no lugar escuro e caliginoso dos futuros e ver e conhecer com a luz não nossa, o que eles viram e conheceram com a sua. ${ }^{11}$

Em relação à História dos historiadores - leia-se História profana - a História de Vieira tem contra si a desvantagem de não poder dispor de uma visão do epílogo, ou seja, o autor não pode apreender, ainda, os sentidos possíveis de um conjunto de episódios ocorridos. Dispõe apenas de uma visão do conjunto de episódios destinados a ocorrer e que estão passando por sua mente num momento privilegiado de iluminação, como se ele estivesse em meio aos transes de eloquência de um sermão.

Portanto, o Vieira historiador do futuro discorre sobre uma certa tendência, que a história das coisas reais normalmente se encarrega de desmentir em breve tempo. A diferença do futurólogo Vieira em relação aos historiadores convencionais, que se debatem com todo tipo de interpretações, a partir de evidências comuns, é que somente ele, Vieira, sabe ler no escuro. $\mathrm{O}$ autor transitava na dimensão das coisas encobertas, apanágio daquele que possui lentes especiais para enxergar nas trevas, revelando com espertezas retóricas de todo tipo os escuríssimos segredos. De seu próprio mundo, no tempo em que vivem, Vieira julgava que os homens podiam alcançar algum conhecimento. Mas, das coisas do passado, o que saberão não será grande coisa. $\mathrm{O}$ que dizer então do conhecimento das coisas que estão por vir? As limitações de um conhecimento dos sucessos nessa dimensão do tempo são ainda mais acentuadas. Do futuro o homem está apartado por uma barreira intransponível.

11 VIEIRA, 2005, p. 228. 
Mas, a curiosidade move-o de tal maneira que ele então recorre a todos os tipos de expedientes para desvendar o que the está reservado, porque se trata de um impulso incontrolável. Contudo, todos os engenhosos recursos empregados para alcançar a ciência dos futuros - como a geomancia, a hidromancia, a aeromancia, a piromancia, etc - são meros desatinos de superstição, como "o ranger da porta, o estalar do vidro, o cintilar da candeia, o topar do pé, o sacudir dos sapatos...". ${ }^{12}$

Mas essa arte de "inquietar o inferno", para extrair revelações que o próprio inferno desconhece, remonta a idades distantes. Isso porque essa "substância" que conhecemos como futuro é enganadora e todos os esforços para dominá-la não passam de sortilégios desencadeados pelo desejo de alcançar o inatingível. Ora, Vieira não tencionava menos do que descrever "feitos heróicos e famosos", antes mesmo de terem se tornado como tais. Então, como pretende superar aquelas dificuldades intransponíveis alegadas quando se trata da ciência dos futuros?

Eis uma operação intelectual que, segundo as exigências do autor, pode até requerer o concurso de instrumentos sobrehumanos. Mas não se pode esquecer - em se tratando do espaço social ocupado por ele e do qual não pretendia abrir mão-, que circunstâncias bem humanas também explicam a arte da profecia. "Estar no poleiro" - para lembrar uma metáfora política utilizada por Eça de Queiroz em O Conde de Abranhos -, e manterse nele, podia requerer alguns malabarismos mundanos como, por exemplo, a sensibilidade visionária de que Vieira deu provas.

Vale lembrar que visões proféticas eram aspecto comum da cultura portuguesa ao tempo de Vieira. Aliás, a crença na intervenção da Providência sobre a história humana era um

${ }^{12}$ VIEIRA, 2005, p. 124. 
aspecto também presente em outras culturas européias. E com maior vigor nos reinos que se consideravam escolhidos por Deus para a realização de uma nova era na história humana. Bossuet quis fazer dos franceses, no reinado de Luís XIV, o novo povo eleito.

O que se pode perceber na História do Futuro é que as suas noções temporais são derivadas de uma visão geográfica. $\mathrm{O}$ autor afirma que, como o mundo, o tempo também está dividido por dois hemisférios. O hemisfério superior é ocupado pelas coisas passadas; o futuro preenche a porção inferior. Percebe-se que a "história vivida" pelos homens numa mesma instituição explícita de tempo - ou seja, o tempo presente e sincrônico de todas as sociedades humanas em diferentes regiões da terra -, é caracterizada por Vieira como "horizontes do tempo". Esses "horizontes" são os instantes que escoam segundo a sensação humana de um devir, de um deslocamento temporal do presente em direção ao futuro.

O futuro que Vieira acredita distinguir nas letras proféticas de um Isaías ou de um Daniel retrata uma humanidade regenerada vivendo uma história superior em qualidade à dos homens do passado. Claramente, o advento desses tempos de maior iluminação marca uma era de regeneração da Cristandade. Esse esforço de imaginação do autor parece implicar algo mais do que a antecipação profética dos sucessos ainda não havidos. Ao depositar nas virtudes inusitadas de sua teoria do tempo da história valores intelectuais que garantiriam o êxito de seu empreendimento literário, é possível supor que existissem intenções autorais que ultrapassavam o simples conteúdo intelectual da obra. Como foi sugerido, Vieira nos faz pensar assim porque ele argumenta no sentido de realçar não apenas a originalidade de sua abordagem, mas também o seu valor instrumental: nada menos do que proporcionar uma forma utilíssima de conhecimento histórico aos poderosos da terra. 
Ora, reflete Vieira, se as ações passadas dos homens sempre são leituras agradáveis quando narradas por historiadores de talento, o que dizer daquela narrativa que se propõe desvendar mistérios insondáveis e que talvez nada fique a dever, quanto aos apetrechos formais, aos maiorais do gênero, sejam eles Antigos ou Modernos? Pela leitura da História do Futuro podese pensar que Vieira imaginou ser possível extrair da admiração provocada por seu novo gênero de História a mais completa fruição literária. Naturalmente, essas são exigências quanto a estilo, forma e conteúdo. Mas, esse artefato intelectual elaborado, que o autor pretendia colocar à disposição de figuras de proa da alta política, não poderia ser o instrumento de tomada das posições disputadas na guerra de guerrilhas travada com seus oponentes desde os quinze anos gloriosos vividos ao lado de D. João IV? Sim, porque da mesma forma que outros autores modernos - Erasmo, Maquiavel, Hobbes, Fénelon, Bossuet Vieira tinha a oferecer as suas lições de História ao príncipe:

Finalmente (e é a terceira e não menor utilidade desta História), lendo os príncipes da Cristandade e, mais particularmente, aqueles que foram ou estão já escolhidos por Deus para instrumentos gloriosos de tão singulares maravilhas e maravilhosas felicidades; lendo, digo, no discurso da História do futuro, as vitórias, os triunfos, as conquistas, os reinos, as coroas e o domínio e sujeição de nações tantas e tão dilatadas que lhes estão prometidas na fé e na confiança das mesmas promessas, se atreverão animosamente a empreendê-las. ${ }^{13}$

Esse escrito profético, no qual deu os primeiros alinhavos provavelmente no ano de $1649,{ }^{14}$ apesar da imensa pretensão

${ }^{13}$ VIEIRA, 2005, p. 164.

14 "A sua História do Futuro, o lucidíssimo sonho utopista, começa a compô-lo em 1649, mas é sobretudo no isolamento das plagas amazônicas que a vai desdobrando, e vivendo". CIDADE, 1973, p. 182. 
empenhada nas esperanças de realizações grandiosas de um reino inexpressivo e em franco declínio, não pode ser julgado como a obra de um lunático. Antes pelo contrário, a História do Futuro é o projeto de um homem já com uma aflorada sensibilidade de percepção das dimensões da crise na qual se embrenhara o Estado monárquico português nos primeiros anos da Restauração. Portanto, a História do Futuro é uma aposta dos aflitos ou, mutatis mutandis, uma "hipótese desesperada", 15 como também é O Príncipe, de Maquiavel.

Com efeito, a História do Futuro começou a ser tramada também num contexto de crise, ou melhor, num momento em que os traços da decadência estavam estampados no colapso financeiro e na ruína do antigo império colonial. E isso sem contar a ameaça da invasão estrangeira. Surgida das circunstâncias mais complicadas da Restauração, a História do Futuro pretendia ser lenitivo para o mal da descrença que se abatera sobre os portugueses. $\mathrm{O}$ autor necessitava, então, de colocar o livro diante dos olhos do príncipe, de interessá-lo por sua aplicação instrumental, como se tratasse de um manual de aconselhamento político que leva à obra da salvação coletiva. Para tanto, ao príncipe caberá assumir o comando da missão posto que será o agente ativo de um futuro que, se já estava previsto, não deixa de carecer das ações deste personagem. A oferta de Vieira também aparece estampada neste outro trecho de seu livro:

E este mesmo escudo, não fabuloso, senão verdadeiro, e não fingido depois de experimentados os sucessos, senão escrito antes de sucederem, é propriamente e sem ficção, o que nesta História do futuro ofereço, Senhor, a Vossa Majestade. ${ }^{16}$

${ }^{15}$ A expressão é, salvo engano, de CHEVALIER, 1999.
${ }^{16}$ VIEIRA, 2005, p. 179. 
A capacidade de um súdito revelar a seu rei o futuro é uma grande coisa. Aliás, é "o maior serviço que pode fazer um vassalo" ${ }^{17}$ As promessas de sua História visam desencadear as ações que se esperam por parte do primaz da política, de modo a conduzir ao bom governo, ao bem comum dos homens, que é consequência natural do reinado de um príncipe instruído pelo conhecimento do futuro. A função do intérprete da misteriosa vontade de Deus é servir de alento ao povo, para fortalecê-lo na esperança e torná-lo mais confiante no porvir. Em Portugal, Bandarra já exercera esse importante papel nos meados do século anterior. Vieira se sentiu à altura para exercêlo também, ainda que na qualidade de um mero intérprete de profecias. ${ }^{18}$ Assim, ele também se tornaria necessário ao povo, porque ao príncipe já provara ser indispensável como o guia seguro de seus passos. Ao rei de Portugal e imperador da Cristandade, ignorar o futuro poderia acarretar efeitos mais danosos do que o desconhecimento do passado.

É certo que a nova História concebida por Vieira - ao manejar certezas inquestionáveis - não é História contra-factual do tipo "como seria o mundo se ocorressem tais e tais episódios". Vieira não se dá a esse esforço mais modesto de ponderar as possibilidades de um futuro se as coisas se passassem dessa ou daquela maneira. O autor sustenta que as coisas hão de passar de uma só maneira e já se podem distinguir nos "horizontes" do tempo - a história vivida - os traços que antecipam o futuro

${ }^{17}$ VIEIRA, 2005, p. 129.

${ }^{18} \mathrm{O}$ livro de Raymond Cantel é obra de interesse sobre o conteúdo visionário das concepções políticas de Vieira. Cf. CANTEL, 1960. Cf. também BOXER, 2002. 
de modo certeiro. ${ }^{19}$ Para ver o futuro se realizando no presente é preciso possuir instrumental próprio para a execução dessas complexas tarefas de antecipação. E o "aparelho de leitura" dos sucessos que estão por vir está "instalado" na rara figura de um narrador apto a descrevê-los para a sua audiência. E Vieira realmente se apresentava como o leitor de profecias, jactandose de que não faria interpretação sem método, de que não escreveria uma narrativa puramente esotérica e metafórica.

Ainda que não se intitule profeta, Vieira pretende situarse alguns patamares acima daquelas figuras misteriosas das Sagradas Escrituras. E, pouco modestamente, julga-se apto a ocupar esses patamares superiores pela superação do próprio Isaías, o profeta mais disciplinado e sistemático do Antigo Testamento, segundo ele mesmo, Vieira. Neste ponto, cabe refletir acerca dos elementos que colocam Vieira na dianteira de figuras de proa como, por exemplo, os próprios profetas bíblicos tão encarecidos por ele. Um desses elementos é evidente: Vieira reconhece situar-se historicamente mais próximo do futuro que há de se realizar e, portanto, pode ver com mais amplitude. Um anão é bem pouca coisa, reconhece o autor. Mas sobre os ombros de um gigante enxerga melhor do que este, diz esse suposto anão acerca do que denomina "prerrogativa do tempo":

Pigmeus nos reconhecemos em comparação daqueles gigantes que olharam antes de nós para as mesmas Escrituras. Eles sem nós viram muito mais do que nós pudéramos ver sem eles; mas nós, como viemos depois deles, e sobre eles por benefício do tempo, vemos hoje o que eles viram, e um

${ }^{19}$ Um historiador escreve que Vieira “... não duvidava que este ou aquele passo das Sagradas Escrituras queria referir-se diretamente a sucessos de seu tempo, de sua Bahia de Todos os Santos ou do Pernambuco apossado pelos holandeses". HOLANDA, 1994, p. 147. 
pouco mais. O último grau da escada não é maior que os outros, antes pode ser menor; mas basta ser o último, e estar em cima dos demais, para que dele se possa alcançar o que dos outros se não alcançava. ${ }^{20}$

Para Vieira, a dilatação do conhecimento colocava os Modernos na dianteira dos Antigos. ${ }^{21}$ Os Modernos são superiores porque estão em condições de "suportar" verdades maiores, como afirmado no Livro de Jó. Aos Modernos cabe desobstruir o desconhecido. Mas as descobertas que fazem não devem implicar falta de reconhecimento para com os predecessores, até porque "acertar em tudo é perfeição de anjos", recorda-se o jesuíta acerca de um preceito de Santo Agostinho. ${ }^{22}$ No final do livro, mais precisamente no "Índice das cousas mais dignas de ponderação que se acham neste livro" Vieira reflete acerca da sabedoria humana nos seguintes termos:

Saber só o que souberam os antigos, não é saber, é lembrarse. Mostra-se com a autoridade dos antigos, que a sabedoria humana não é limitada e que em todos os séculos se podem produzir e inventar cousas novas. ${ }^{23}$

Pensando assim, Vieira toma o partido dos Antigos em seus diálogos das grandezas dos homens através dos tempos. E a dinâmica que estabelece entre Antigos e Modernos é uma fronteira temática extremamente rica no curso de toda a História do Futuro. Como autor moderno - pelas circunstâncias inescapáveis da cronologia - ele queria primar pelo estilo claro, pelo domínio de leis da história, pela exploração dos eventos materiais e

\footnotetext{
${ }^{20}$ VIEIRA, 2005, p. 241.

${ }^{21}$ Cf. VIEIRA, 2005, p. 279ss.

${ }^{22}$ Cf. VIEIRA, 2005, p. 290.

${ }^{23}$ VIEIRA, 2005, p. 482s.
} 
humanos. Em sua concepção, a História do Futuro é um gênero tão original a ponto de o próprio autor se comparar a Noé, quando tragado pelo dilúvio: nunca houve um caso parecido.

A idéia de uma História Perfeita, ${ }^{24}$ no sentido de apresentar interpretações não apenas prováveis e possíveis, mas verdadeiramente infalíveis, pode ser percebida na consciência do autor. Mas, é certo que a História Sagrada de Vieira prescinde do juízo de autoridade dos autores profanos antigos. A verdade não está na autoridade de um Tácito que, para Vieira - endossando a opinião de Tertuliano sobre o autor da Germânia-, foi o "mais loquaz dos mentirosos".

De fato, Vieira não perde a oportunidade de destacar a originalidade de seu experimento. Ora, ele pretende nada menos do que fazer obra à altura de Moisés, que descobriu, por revelação divina, o passado desconhecido. Até então, o que fora dito nos reinos da História era pura "contradição da verdade". Para Vieira, apenas a sua História é verdadeira. A diferença qualitativa entre a sua e as demais narrativas está na natureza das fontes que emprega. A História profana dos historiadores foi tecida pelo emprego de evidências incertas. A sua, além de vir de fonte limpa, ainda é clareada pelo "lume da razão".

Vieira compreendia que o seu gênero de História era uma síntese de todas as decisões da Providência. Como ninguém conseguira ainda produzir tal síntese, ele se apresentava como o portador das credenciais para abraçar uma causa dessa envergadura. Dessa forma, ele será um "instrumento pequeno"

\footnotetext{
${ }^{24}$ A expressão foi explorada pelo historiador norte-americano George Huppert em seu livro The Idea of Perfect History. Na segunda metade do século XVI, analisa Huppert, houve na França um conjunto de juristas e historiadores que julgaram ter alcançado uma compreensão completa do passado fiando-se na abordagem rigorosa dos documentos.
} 
para uma "grande cousa", segundo os expedientes de que Deus lança mão:

E isto é o que eu começo a fazer, com a graça daquele Senhor que sempre se serve de instrumentos pequenos em cousas grandes, para que conheça o Mundo e Portugal, com os olhos sempre no Céu e em Deus, que tudo são efeitos de seu poder e conselhos da sua Providência. ${ }^{25}$

Mas qual o sentido da elaboração de tão grande obra de pensamento? Para Vieira, o sentido está na percepção de que a Deus apraz revelar aos homens os seus desígnios, para o bem e para o mal. Tudo o que ocorre, segundo a sua concepção providencialista da realidade, é consequência do único motor da história humana. Deus é autor da abundância e da esterilidade, da tempestade e da bonança, da conservação e da ruína. A "fortuna" e "indústria humana" são guiadas pelas disposições divinas. Deus opera diretamente sobre a natureza, faz e desfaz os "portentos" e as "maravilhas". Pensar diferentemente é abrir caminho para a descortesia, a blasfêmia e a ingratidão, segundo as suas próprias palavras. Mas, se a radical originalidade da obra do jesuíta está na utilidade de conhecer o futuro, que importância será reservada ao papel dos exemplos das coisas passadas? Não se pode esquecer que, ao tempo de Vieira, o gênero da "História Mestra da Vida" tinha presença marcante nas obras produzidas na Europa ocidental.

A boa História no século XVII era predominantemente concebida pelos historiadores como um exercício estilístico, para a fruição literária do leitor. Uma narrativa tecida com talento era uma exigência do público da época, não resta dúvida. Mas essa História não era arquitetada apenas como simples

${ }^{25}$ VIEIRA, 2005, p. 146. 
literatura, em que um autor tencionava suplantar o outro explorando um mesmo tema. No tempo de Vieira, a arte de narrar acontecimentos passados para evocar o patriotismo nos súditos de sua Sereníssima Majestade ainda fazia escola. “Os processos demonstrativos do passado continuavam em vigor", explicam António José Saraiva e Óscar Lopes, mesmo que "as motivações dos homens fossem outras" ${ }^{26}$

Entranhado nesse civismo estava o conteúdo de exemplaridade dos acontecimentos, como o que pode ser percebido nas Epanáforas de Vária História Portuguesa, de D. Francisco Manuel de Melo, obra da segunda metade do século XVII. Sim, havia lições práticas a se extrair dos exemplos das coisas passadas, para servir à construção do futuro. Certamente, os motivos morais que qualificavam o que os historiadores seiscentistas portugueses concebiam como as melhores ações em prol da coletividade não foram os únicos fios condutores da narrativa histórica. Mas, como em toda a Europa ocidental, ainda estavam em evidência no século XVII, e mais além. ${ }^{27}$

Nesse sentido, Vieira foi um inovador. Isso porque, todas as consequências de uma história do futuro são projeções dos episódios narrados por fontes literárias muitíssimo antigas, segundo as novas decodificações de um tradutor qualificado como Vieira. Comparando-o a Bossuet, que no século XVII é, por assim dizer, o seu "contraponto natural", a História do Futuro de Vieira poderia intitular-se A história extraída das Sagradas Escrituras, ${ }^{28}$ tal o predomínio dessas fontes sobre todas as demais evidências de sua base documental.

${ }^{26}$ SARAIVA; LOPES, 1996, p. 521.

${ }^{27}$ Para um estudo do gênero Historia magistra vitae ver: KOSELLECK, EHESS, 1990.

${ }^{28}$ Assim o próprio Vieira diz textualmente. Cf. VIEIRA, 2005, p. 156. 
Mas, está claro, existem diferenças significativas entre ambos, em termos de visadas teóricas e planos históricos: "Bossuet, principal figura intelectual da Igreja Francesa - o 'último doutor da Igreja' - substituiu, quanto possível, a alegoria bíblica ou a sutileza escolástica por uma oratória que se dirige ao senso comum do público geral contemporâneo e à sua imaginação, e que está muito mais próximo da eloquência ciceroniana do que da pregação medieva". ${ }^{29}$ Ao contrastá-lo com Bossuet, Saraiva \& Lopes acentuam a evidência de que Vieira é autor extremamente denso em matéria de imagens de toda ordem, com destaque para o emprego de metáforas bíblicas e naturais. Acerca desses paralelos frequentes entre ambos, Hernani Cidade argumenta que "Quando se compara Vieira com Bossuet (...) reconhece-se a mais funda gravidade do pensamento deste, o maior bulício vital da imaginação daquele. Assim é. Bossuet era o tipo do homem de pensamento e pôde sê-lo exclusivamente, num grande país em que tantos estímulos lho expunham em exercício. Vieira era o tipo de homem de ação, e foi para ela, exercida como missionário, político e diplomata, que mil circunstâncias o impeliram". ${ }^{30}$

Sem dúvida, o esquema alegórico é pertinente como elemento de análise das imagens régias no pensamento histórico e político de Vieira. Nos textos históricos e políticos escritos por ele é sempre possível identificar recorrências desses esquemas alegóricos. Como lembra um teórico da literatura, Antoine Compagnon, "a alegoria é uma interpretação anacrônica do passado, uma leitura do antigo, segundo o modelo do novo, um ato hermenêutico de apropriação: à intenção antiga ela substitui

${ }^{29}$ SARAIVA; LOPES, 1996, p. 521. De um ponto de vista quase exclusivamente literário, ver a análise de MARTINS, 1978, v. 1, p. 203ss. ${ }^{30}$ CIDADE, 1973, p. 186. 
a dos leitores. (...) A alegoria é um instrumento todo poderoso para inferir um sentido novo num texto antigo". ${ }^{31}$

Como salienta Eric Auerbach, "durante a Idade Média européia era possível, ainda, representar os acontecimentos bíblicos como sucessos quotidianos contemporâneos, para o que o método exegético fornecia as bases". ${ }^{32}$ Segundo a análise desenvolvida por Auerbach - que está focada na literatura medieval, e mais especificamente na obra de Santo Agostinho - “o acontecimento sensorial empalidece, sobrepujado pela significação figurada". ${ }^{33}$ Nos círculos eclesiásticos seiscentistas essa forma de representação da realidade histórica ainda exercia bastante influência. Na História do Futuro é possível identificar numerosas exemplificações desses esquemas alegóricos.

No Século das Luzes, Voltaire identificou as "alegorias" da Bíblia presentes nas obras históricas e, naturalmente, se divertiu com as intrusões do anacronismo na análise da história. No verbete "Apocalypse", do Dicionário Filosófico, ele afirmou que "Cada comunidade cristã atribui a si mesma as profecias encontradas neste livro; os ingleses descobriram nele as revoluções da Grã-Bretanha; os luteranos, as guerras civis na Alemanha; os reformados franceses, o reinado de Carlos IX e a regência de Catarina de Médicis: todos tinham razão". ${ }^{34}$ Contudo, o método alegórico de interpretação do passado era indiferente ao que chamamos, hoje, anacronismo. À época de Voltaire isso também já era evidente entre leitores cultos e, tanto mais ainda, pelos esforços de historiadores pertencentes às

${ }^{31}$ COMPAGNON, 2001, p. 56s.

${ }^{32}$ AUERBACH, 2002, p. 12s.

${ }_{33}$ AUERBACH, 2002, p. 41.

${ }^{34}$ VOLTAIRE, 1994, p. 75. 
ordens religiosas como, por exemplo, a dos beneditinos e a dos próprios jesuítas. $^{35}$

Mas, se Vieira tivesse se preocupado com a historicidade dos fenômenos que narrou em sua História do Futuro, talvez não fosse o jesuíta genial que reconhecemos. Ele seria, possivelmente, mais um simples nome em meio aos demais escritores seiscentistas portugueses, dos quais a escola histórica de Alcobaça dá bom testemunho. ${ }^{36} \mathrm{O}$ improvável e o espetacular em suas contextualizações históricas é o que há de mais interessante em suas interpretações.

Isso pode significar, aos olhos do historiador de nossos dias, que uma história seiscentista seria essencialmente uma história anacrônica, que deveria se ajustar às exigências do saber histórico, no contexto de sua produção: História Sagrada, História Teológico-Política, História Teleológica, História Epifânica, como ressalta Alcir Pécora, na qual se lê "o desfecho gradual das profecias, a aproximação tão milagrosa quanto natural e cotidiana de Deus". ${ }^{37}$

E o aspecto de curiosidade excêntrica da alegoria que se pode distinguir em Vieira é o fato de suas análises implicarem a possibilidade de uma transposição livre dos valores morais no tempo. No "Sermão de São Roque” (Lisboa, Capela Real, 1644), e apenas a título de ilustração dessas questões recorrentes, lemos que um soberano da Antiguidade bíblica já comungava da

${ }^{35}$ Cf. LEFEBVRE, 1974.

${ }^{36}$ Frei Bernardo de Brito (1569-1617) é o nome mais conhecido da "Escola de Alcobaça". Ingressou na Ordem de Cister em 1585. Em 1606, tornou-se cronista-mor da Ordem. Em 1606, no reinado de Filipe III, foi nomeado cronista-mor do reino. A primeira e segunda partes da Monarquia Lusitana são de sua autoria. Escreveu também a Crônica de Cister.

${ }^{37}$ PÉCORA, 1994, p. 262. 
mesma fé do autor, que dessa forma antecipa o catolicismo em ao menos um milênio de história:

Um rei tão católico, como Davi, há de fazer a coroa da sua cabeça do ouro dos ídolos? Sim. Antes, por isso mesmo, porque não pode haver mais gloriosa indústria em um rei que saber passar à sua coroa o mesmo ouro que enriquece os ídolos. Este ouro está servindo à infidelidade: pois quero eu que sirva à minha coroa - diz el-rei Davi. (...) Servir à fé com as armas da infidelidade, oh! que política tão cristã! Alcançar a fé as vitórias, e pagar a infidelidade os soldados, oh! que cristandade tão política! ${ }^{38}$

Inexistindo a idéia de diferenças substantivas na noção do tempo histórico no sistema teórico dos cronistas e historiógrafos da Europa barroca - Vieira incluído -, bem natural seria que o comércio livre das idéias cristãs no tempo não significasse necessariamente ausência da noção de contexto histórico nas obras históricas daquele tempo. E isso tanto nas Histórias de Vieira como nas dos historiógrafos de Alcobaça. Assim é que interpretar a história de maneira alegórica parece implicar em conceder muito pouca ou nenhuma importância às diferenças culturais de sociedades afastadas entre si às vezes por milênios, como a Palestina dos profetas bíblicos e o Portugal barroco e messiânico no tempo da Restauração.

Por suas intervenções muitas vezes consideradas impertinentes pelos adversários, Vieira foi denunciado à Inquisição portuguesa, a propósito de judaísmo e também pelas idéias proféticas de seu imaginativo Quinto Império. ${ }^{39}$ De fato,

\footnotetext{
${ }^{38}$ In: PÉCORA, 2003, p. 55.

39 "Por quê Quinto? António Vieira baseia-se numa interpretação que tinha sido dada às profecias bíblicas de Daniel dos cinco impérios sucessivos, entendendo neles o assírio, o persa, o grego, o romano e, por fim, na visão do jesuíta, o império português". TELMO, 1997, p. 104.
} 
trata-se de leituras bem visionárias das Sagradas Escrituras. Vieira torce e retorce textos, usa e abusa dos direitos de sua "fornalha da imaginação" (António Sérgio), em tempos não mais seguros para "leitores de entranhas". Acerca dessa expressão, talvez caibam algumas palavras que elucidem o seu emprego para a caracterização de Vieira, pois não basta partir da evidência de que ele era intérprete de mistérios. Como explica Maquiavel, nos Discorsi, o costume dos antigos de consultar livros sibilinos, auspícios, augúrios, etc., possuía apenas uma finalidade: atiçar o ânimo das tropas, incitar a coragem dos soldados, torná-los confiantes para os combates, "pois a confiança gera quase sempre a vitória". ${ }^{40}$ Ora, como um engajado intérprete de mistérios, para servir à construção de um projeto político, é possível pensar em Vieira como líder de infantaria, o homem que marcha à frente das tropas transmitindo a mensagem de ânimo, ao mesmo tempo em que vai anunciando os prenúncios do êxito.

Com a morte de D. João IV e, alguns anos mais tarde, com o término da regência de Dona Luísa de Gusmão, iniciaram-se as suas desventuras. Até então ele era um dos mais prestigiados cortesãos. Alcançado finalmente por seus adversários, mutatis mutandis, ele logo se vê tão desarmado como o Savonarola descrito por Maquiavel. $\mathrm{O}$ amigo do rei não conta mais com os seus patronos. O tribunal da Inquisição de Coimbra requisitao nos inícios da década de 1660. Habilidade e eloquência não bastavam mais para manter esse poço de idéias livre da ira de seus antagonistas.

Corria o ano de 1663, estando em curso o efêmero e instável reinado de D. Afonso VI. Seguindo a orientação de sua Ordem religiosa, Vieira havia apoiado poucos anos antes a ascensão de D. Pedro, o irmão caçula do herdeiro. Com os ventos a seu favor,

${ }^{40}$ MAQUIAVEL, [s.d.], p. 70. 
era fácil polemizar sem o temor de afrontar os interesses de inquisidores fanáticos, a equívoca e volátil opinião popular e a conservadora vontade dos nobres. Sem dúvida, num tempo em que a política fazia da religião um campo minado, era sempre atitude de risco a mais leve heterodoxia.

Mas o fato mais certo é que a História do Futuro foi o investimento profético no qual Vieira traçou o projeto de uma nova era, os mil anos gloriosos dos eleitos sobre a terra. Nessa Cristandade regenerada, o novo monarca universal não dividiria o seu poder com nenhum outro ator político secular; mas ele o compartilharia com o imperador espiritual da Cristandade. ${ }^{41}$ Ao que parece, cometer um esforço intelectual da magnitude da História do Futuro não era tarefa para, simplesmente, cair no espaço ocupado por pessoas intelectualmente ociosas e politicamente desatentas.

Em se tratando, inegavelmente, de uma grande obra, nada haveria de negativo em alardear este imenso bem cometido em nome da comunidade. E, comojá dito, o autor visava um conjunto de leitores importantes que lhe aprovassem o esforço. Se havia um diferencial em sua História do Futuro que de fato pudesse impressionar as mentes mais conservadoras, Vieira pensava que o tempo se encarregaria de dizer que o autor tinha razão. De suas próprias circunstâncias - haja vista que os seus textos proféticos foram requisitados pela Inquisição nos inícios do reinado de D. Afonso VI -, Vieira sacou o exemplo de São Jerônimo. A sua Vulgata não fora perseguida e condenada em seu tempo?

${ }^{41}$ Como adverte um dos mais atentos leitores de Vieira, o Quinto Império seria "... um cetro ao lado de um báculo, para a consumação do reinado de Cristo na terra, e nele integrados, pela conversão, todos os judeus, todos os maometanos e todos os gentios". CIDADE, 1973, p. 183. 
E que brilhante futuro se descortinou para a sua tradução! O triunfo de suas próprias verdades logo deveria mostrar os seus vigorosos efeitos. Questão de tempo, iludia-se Vieira. Ora, o projeto político no qual ele investiu uma parte considerável de seus talentos era uma realidade já superada pelos Tempos Modernos. De fato, quimérica foi a visão de Vieira, que apostou na idéia de império em plena época de ascensão das monarquias nacionais.

\section{Bibliografia}

AUERBACH, Eric. Mimesis: a representação da realidade na literatura ocidental. São Paulo: Perspectiva, 2002.

BESSELAAR, José van den. António Vieira: o homem, a obra, as idéias. Lisboa: Biblioteca Breve, 1982.

BOXER, Charles. Sebastianismo, messianismo e nacionalismo. In: $O$ império marítimo português. São Paulo: Companhia das Letras, 2002.

CANTEL, Raymond. Prophétisme et messianisme dans l'oeuvre d'Antonio Vieira. Paris: Hispano-Americanas, 1960.

CHEVALIER, Jean-Jacques. O Príncipe, de Maquiavel. In: As grandes obras de Maquiavel a nossos dias. Rio de Janeiro: Agir, 1999.

CIDADE, Hernani. Portugal Histórico e Cultural. Lisboa: Círculo de Leitores, 1973.

COMPAGNON, Antoine. O demônio da teoria: literatura e senso comum. Belo Horizonte: Editora UFMG, 2001.

ELIADE, Mircea. Lo sagrado y lo profano. Madrid: Guadarrama, 1970. HOLANDA, Sérgio Buarque de. Visão do paraíso. São Paulo: Brasiliense, 1994.

KOSELLECK, Reinhart. Le futur passé. Contruction à la sémantique des temps historiques. Paris: EHESS, 1990. 
LEFEBVRE, Georges. El nascimiento de la historiografia moderna. Barcelona: Martinez Roca, 1974.

MARTINS, Wilson. História da inteligência brasileira. São Paulo: Cultrix/Edusp, 1978, Vol. 1.

PÉCORA, Alcir. Política do céu - anti-Maquiavel. In: NOVAES, Adauto. (Org.). Ética. São Paulo: Companhia das Letras, 1999.

PÉCORA, Alcir. Teatro do Sacramento: a unidade teológico-retóricopolítica dos sermões de Antônio Vieira. São Paulo: Edusp, 1994.

RONCARI, Luiz. Padre Antônio Vieira e a literatura do púlpito. In: Literatura brasileira: dos primeiros cronistas aos últimos românticos. São Paulo: Edusp, 1995.

SARAIVA, António José; LOPES, Oscar. Pe. António Vieira. In: História da literatura portuguesa. Porto: Porto Editora, 1996.

TELMO, António. António Vieira e a idéia do Quinto Império. In: História secreta de Portugal. Lisboa: Editorial Vega, 1997.

VIEIRA, Antônio. História do Futuro. Brasília: Editora da UnB, 2005.

VIEIRA, Antônio. Sermão de ação de graças pelo nascimento do príncipe D. João, primogênito de SS. Magestades, que Deus guarde (1688). In: Obras completas do padre Antonio Vieira. Porto: Lello \& Irmão. Volume XV, 1951.

VIEIRA, Antônio. Sermão de São Roque. In: PÉCORA, Alcir. (Org.). Escritos Históricos e Políticos. São Paulo: Martins Fontes, 2003.

VIEIRA, Antônio. Sermão de Santo Antonio. In: CALMON, Pedro. (Org.). Sermões Patrióticos. Rio de Janeiro: Edições Biblos, 1933. 


\section{Resumo}

Em sua concepção de História Sagrada o padre Antônio Vieira combinou a realidade efetiva das coisas vividas - a experiência dos atores no tempo presente - com o projeto divino traçado por Deus nas Escrituras. A realidade histórica está vinculada a um plano superior, que Vieira se encarrega de desvendar. É bom lembrar que o plano divino não exclui a participação dos homens, absolutamente necessária para o desenlace dos acontecimentos. Assim, a história do reino vai sendo encadeada. Ações humanas e assistência divina hão de levar a um grande futuro. O gênero de História do padre Vieira pretende desembaçar, aos olhos dos príncipes, segredos e mistérios "ocultos e escuríssimos" que requerem um tipo de entendimento privilegiado.

\section{Abstract}

In his conception of sacred history Father Antonio Vieira matched the actual reality of living things - the experience of the actors in the present time - with the divine plan outlined by God in Scripture. The historical reality is linked to a higher plane, which is responsible for Vieira unravel. Remember that God's plan does not exclude the participation of men, absolutely necessary to the outcome of events. Thus, the history of the kingdom will be chained. Human actions and divine assistance they will lead to a great future. Gender History of Father Vieira intends defroster, in the eyes of the princes, secrets and mysteries that require a kind of understanding privileged. 